\title{
THE RIGHT TO COUNSEL IN MISDEMEANOR CASES
}

\begin{abstract}
The right to be heard would be, in many cases, of little avail if it did not comprehend the right to be heard by counsel. Even the intelligent and educated layman lias small and sometimes no skill in the science of law. If charged with crime he is incapable, generally, of determining for himself whether the indictment is good or bad. He is unfamiliar with the rules of evidence. Left without the aid of counsel he may be put on trial without a proper charge, and convicted upon incompetent evidence, or evidence irrelevant to the issue or otherwise inadmissible. He lacks both the skill and knowledge adequately to prepare his defense, even though be bave a perfect one. $\mathrm{He}$ requires the guiding hand of counsel at every step in the proceedings against him. Without it, though he be not guilty, he faces danger of conviction because he does not know how to establish his innocence. ${ }^{1}$
\end{abstract}

These words of Mr. Justice Sutherland in Powell v. Alabama are a clear statement of the importance of the defendant's right to counsel in a criminal proceeding. The right to counsel has been the source of much controversy in the last twenty-five years, as is evidenced by the voluminous literature devoted to its discussion. ${ }^{2}$ Only infrequently, however, has the right of the defendant in a misdemeanor case been considered. This is not surprising when one considers that only in recent times has a right to counsel in more serious cases received recognition by the courts and legislatures.

In considering the defendant's right to counsel in misdemeanor cases it is necessary to recognize that there must be a balancing of two opposing interests-the interest of the defendant in having his case disposed of with fairness, and the interest of the state in administering an effective systein of criminal law. It is the purpose of this Comment to determine where the balance has been struck and to reflect upon the wisdom of this balance.

\section{HISTORICAL BACKGROUND-FELONY CASES}

In order to understand the problem which is presented in misdemeanor cases, it is important to trace the developinent of the right to counsel in felony cases. The reader inust bear in mind the distinction which will be made between the right to aid of counsel retained by the accused and the right of the indigent defendant to have counsel appointed to represent him.

\section{A. Englisk Common Laws}

At early common law defendants in misdemeanor cases were allowed full representation by retained counsel, but defendants accused of felonies or treason

1 Powell v. Alabama, 287 U.S. 45, 68-69 (1932).

2 See, e.g., Beaney, The Right to Counser in Averican Courts (1955); Fellman, The Right to Counsel Under State Law, 1955 Wis. L. REv. 281; Fellman, The Federal Right to Coursel in State Courts, 31 NEB. L. REv. 15 (1951); Fellman, Tke Constitutional Right to Coussel in Federal Courts, 30 NEB. L. Rev. 559 (1951); Holtzoff, The Right of Counsel Under the Sixth Amendment, 20 N.Y.U.L. Rev. 1 (1944); Note, 97 U. PA. L. Rev. 855 (1949).

3 This discussion is based on the following materials: BEANEY, op. cit. suppra note 2, at 8-14; Grant, Our Common Law Constitution, 40 B.U.L. REv. 1 (1960); Heidelbaugh \& Becker, The Right to Counsel in Criminal Cases-an Inquiry into the History ard Practice in England and America, 28 Notre Daure Law. 351 (1953); Heidelbaugh \& Becker, Blackstone's Use of Medicval Law in Criminal Cases Involving Benefit of Cosmsel, 7 Mraur L.Q. 184 (1953); Heidelbaugl \& Becker, Benefit of Counsel in Criminal Cases in the Time of Coke, 6 Mrnar L.Q. 546 (1952); Holtzoff, supra note 2. 
were not. It did become customary for the courts to allow counsel to assist on specific legal points in these more serious cases, but there was a rule against allowing counsel on questions of fact or for general argument.

In 1695 Parliament passed a statute which allowed full defense by counsel in treason cases and which provided that the court must appoint counsel at the request of the defendant. Those accused of felonies, however, still could not be represented by counsel. But by 1769 the rules in regard to felonies were relaxed so that counsel was able to represent the accused at every stage of the trial, with the exception of presenting closing arguments to the jury.

In 1836 it was provided by statute that counsel could be retained in all cases. Not until relatively recent times, however, has there been statutory authority in England to appoint counsel in felony cases. The divergence of opinion as to what was the early practice leads one to the conclusion that there was no standard rule. ${ }^{4}$

\section{B. Federal Courts ${ }^{5}$}

The sixth amendment, adopted at a time when England was just beginning to permit retained counsel in felony cases, is applicable only to prosecutions in federal courts. ${ }^{6}$ It provides:

In all criminal prosecutions, the accused shall enjoy the right . . . to have the Assistance of Counsel for his defence. ${ }^{7}$

Prior to the Supreme Court's decision in Johnson v. Zerbst (1938), ${ }^{8}$ the right of the defendant "to have the Assistance of Counsel for his defence" was generally understood to mean that a defendant in a criminal case was entitled to be represented by counsel retained by him..$^{9}$ It was thought that the trial judge was under no obligation to appoint counsel for an indigent defendant, except where required by statute. ${ }^{10}$ As a matter of practice, however, prior to 1938 some federal courts did assigu counsel to indigent defendants in the trial of grave offenses, except where the defendant desired to conduct his own clefense. But some courts would not appoint counsel for the defendant unless lie expressly requested such appointment, and the common practice was not to make an appointment when the defendant pleaded guilty. ${ }^{11}$ This procedure was radically altered by Jolnnson v. Zerbst, where the Supreme Court held that the sixth amendment is not limited to the right of being represented by retained counsel, but that the defendant in a felony case has a riglit to appointed counsel if for financial or other reasons he is unable to secure counsel himself. The Court stated, however, that the right to

\footnotetext{
4 See, especially, the articles by Heidelbaugh and Becker in note 3 supra.

5 For a detailed study see: BEANEY, op. cil. supra note 2, at 27-79; Fellman, The Constitutional Right to Counsel in Federal Courts, 30 NEB. L. REv. 559 (1951); Holtzoff, supra note 2.

6 Bute v. Illinois, 333 U.S. 640 (1948); Betts v. Brady, 316 U.S. 455 (1942).

7 U.S. Const. amend. VI.

8304 U.S. 458 (1938).

${ }^{9}$ BeANEY, op. cit. supra note 2, at 77; Holtzoff, supra note 2, at 7. President Hoover's Wickersham Commission dismissed the clause with the statement: "[T] $]$ he right guaranteed is one of employing counsel, not one of having counsel provided by the Government." U.S. NaT'L Comm's on Law Observance and Enforcement, Report on Prosectition 30 (1931).

10 Since 18 U.S.C. $\$ 563$ (now 18 U.S.C. $\$ 3005$ (1958)) provided that counsel must be assigned in capital cases, it seems evident that Congress supposed that the sixth amendment was not the source of any such guarantee in other cases; otherwise the statute would be superfluous.

11 Holtzoff, supra note 2, at 8.
} 
appointed counsel could be waived by a defendant if it were done competently and intelligently. ${ }^{12}$

In 1945, the holding of the Johnson case became the substance of Rule 44 of the Federal Rules of Criminal Procedure:

If the defendant appears in court without counsel, the court shall advise him of his right to counsel and assign counsel to represent him at every stage of the proceeding unless he elects to proceed without counsel or is able to obtain counsel.

\section{State Courts}

The state constitutions early provided that a defendant in a criminal case should have the right to be represented by counsel retained by him. ${ }^{13}$ It seems apparent that this was done to prevent the inequity which resulted from the early English practice. With regard to the appointment of counsel, the discretion of the trial judge was usually controlling.14

Not until 1932 was the United States Suprene Court called upon to decide a case in which the right to counsel in a state court figured prominently. ${ }^{15}$ In that year, in the leading case of Powell v. Alabama, ${ }^{16}$ the Court held that there was a denial of due process where a state trial court failed to make an effective appoint$m e n t^{17}$ of counsel in a capital case. Even though Mr. Justice Sutherland clearly limited the holding to capital cases, ${ }^{18}$ the rest of the opinion gave the impression that a broader riglit to appointed counsel might exist.

Ten years later this impression was confirmed by the decision in Betts $v$. Brady. ${ }^{19}$ Defendant, accused of burglary in a state proceeding, had requested and had been denied appointment of counsel. The Court held, in affirming his conviction, that it is only "in certain circumstances, or in connection with other elements" 20 that the denial of a specific provision of the Bill of Rights is also a

12 The Court summarized as follows: "If the accused, bowever, is not represented by counsel and has not competently and intelligently waived his constitutional right, the Sixth Amendment stands as a jurisdictional har to a valid conviction and sentence depriving him of his life or his hiberty. A court's jurisdiction at the beginning of the trial may be lost in the course of the proceedings' due to fallure to complete the court-as the Sixth Amendment requires-by providing counsel for an accused who is unable to obtain counsel, who has not intelligently waived this constitutional guaranty, and whose life or hiberty is at stake. If this requirement of the Sixth Amendinent is not complied with, the court no longer has jurisdiction to proceed. The judgment of conviction pronounced by a court without jurisdiction is void, and one imprisoned thereunder may obtain release by habeas corpus." 304 U.S. at 468.

13 See BEANEY, op. cit. supra note 2, at 18 . There it is pointed out that the right in practice might not have heen as broad as the right ostensibly granted by constitution and statute.

14 See BEANEY, op. cit. supra note 2, at 25 .

15 Reference to the right was made in Frank v. Mangum, 237 U.S. 309 (1915), where 2 claim that a trial was mob-dominated was rejected, the court noting that the defendant had "had a puhlic trial, deliberately conducted, with the benefit of counsel for his defense . ..." 237 U.S. at 344. In Moore v. Dempsey, 261 U.S. 86 (1923), a trial was held not to meet the requirements of due process where mob pressure affected the conduct of counsel, jury, and judge.

16287 U.S. 45 (1932).

17 The trial court's appointment of the entire local bar and the latter's subsequent inaction was not an effective appointunent. Id. at 53-57.

18 "All that is necessary now to decide, as we do decide, is that in a capital case, where the defendant is unable to employ counsel, and is incapable adequately of making his own defense because of ignorance, feeblemindedness, illiteracy, or the like, it is the duty of the court, whether requested or not, to assign counsel for him as a necessary requisite of due process of law ..." 287 U.S. at 71 .

10316 U.S. 455 (1942).

20 Id. at $462-63$. 
denial of due process under the fourteenth amendment. With regard to the right to counsel, the Court stated that no definite criteria could be established, since the concept of due process is "less rigid and more fluid"21 than the requirements of the first eight amendments; the asserted denial of the right is to be "tested by an appraisal of the totality of facts in a given case." $22 \mathrm{Mr}$. Justice Roberts, speaking for the Court, pointed out that the question of appointment of counsel had been settled by legislative policy in different ways in the various states and that at common law there existed no right to appointed counsel. ${ }^{23}$ These two facts were used to support the proposition that the "appointment of counsel is not a fundamental right essential to a fair trial." 24 The Court concluded that "while want of counsel in a particular case may result in a conviction lacking in such fundamental fairness, we cannot say that the amendment embodies an inexorable command that no trial for any offense, or in any court, can be fairly conducted and justice accorded a defendant who is not represented by counsel." 25

In the right to counsel cases which have been before the Supreme Court since Betts v. Brady, the Court has not formulated a more precise rule as to when the right to appointed counsel accrues. ${ }^{2 B}$ In deciding whether there has been a fair trial where appointment of counsel has been denied, the Court has looked to the gravity of the crime, ${ }^{2 \pi}$ the age and education of the defendant, ${ }^{28}$ the conduct of the court and the prosecuting officials, ${ }^{2 \theta}$ and the complicated nature of the offense charged and possible defenses thereto. ${ }^{30}$

In all cases involving the fairness of state criminal proceedings, there are two underlying, opposing considerations, the balancing of which constitutes an important factor in the determination of each case. The first is the delicate issue of federalism. ${ }^{31}$ Since all states provide methods by which criminal prosecutions may

21 Id. at 462 .

22 Ibid. (Emphasis added.)

23 This conclusion has been attacked, the contention being that the right to assigninent of counsel at common law was much broader than that recognized in Betts $v$. Brady. See the articles by Heidelbaugh and Becker in note 3 supra.

24316 U.S. at 471 (1942).

25 Id. at 473 .

26 One writer feels that the elements are presently clear enough so that a prediction as to the result of a right to counsel case can be made with fair accuracy by using a mathematical formula allocating points for various types of infringements. Kort, Predicting Supreme Court Decisions Mathematically: A Quantitative Analysis of the "Right to Counsel" Cases, 51 Axs. Por. Scr. Rev. 1 (1957).

27 See, e.g., Uveges v. Pennsylvania, 335 U.S. 437, 441 (1948); Powell v. Alabama, 287 U.S. 45,71 (1932).

28 See, e.g., Wade v. Mayo, 334 U.S. 672, 683-84 (1948); De Meerleer v. Micbigan, 329 U.S. 663, 664-65 (1947); Betts v. Brady, 316 U.S. 455, 472 (1942); Powell v. Alabama, 287 U.S. 45, 51-52 (1932).

${ }^{29}$ See, e.g., Townsend v. Burke, 334 U.S. 736, 739-41 (1948); De Meerleer v. Michigan, 329 U.S. 663,665 (1947); Smith v. O'Grady, 312 U.S. 329, 332-33 (1941).

${ }^{30}$ See, e.g., Rice v. Olson, 324 U.S. 786, 789-91 (1945).

31 In Cicenia v. Lagay, 357 U.S. 504, 510 (1958), the Court stated: "This Court has often recognized that it is of the 'very essence of our federalisin that the States should have the widest latitude in the administration of their own system of criminal justice'." In Avery v. Alabama, 308 U.S. 444, 446-47 (1940), Mr. Justice Black stated: "In deternnining whether petitioner has been denied his constitutional right to assistance of counsel, we must remeinber that the Fourteenth Amendment does not limit the power of the States to try and deal with crimes committed within their borders, and was not intended to bring to the test of a decision of this Court cvery ruling made in the course of a state trial. Consistently with the preservation of constitutional balance between state and federal sovereignty, this Court must respect and is reluctant to interfere with the states' determination of local social policy." 
be reviewed, the Supreme Court is understandably reluctant to overrule the highest court of a state, especially where the violation of a federal right is at least doubtful and the state court's decision is not without foundation. The second consideration is the desire to develop basic standards of fairness to govern state criminal proceedings.

II

THE PRESENT RIGHT IN MISDENEANOR CASES

\section{A. Federal Courts}

Under a federal statute ${ }^{32}$ public offenses are divided into three categories:

Notwithstanding any Act of Congress to the contrary: (1) Any offense punishable by death or imprisonment for a term exceeding one year is a felony. (2) Any other offense is a misdemeanor. (3) Any misdemeanor, the penalty for which does not exceed imprisonment for a period of six months or a fine of not more than $\$ 500$, or both, is a petty offense. 33

There is no doubt that a defendant accused of any of the three types of offenses has a right to be represented by counsel retained by him. The language of the sixth amendment seems clear in guaranteeing this right. Moreover, Rule 5(a) of the Federal Rules of Criminal Procedure provides that the arrested person must be taken without delay to the nearest available commissioner, who must, under Rule 5(b), inform the defendant of his right to retain counsel and allow him a reasonable time and opportunity to consult with counsel. ${ }^{34} \mathrm{~A}$ greater problem is presented with respect to the right to appointment of counsel.

\section{Misdemeanors ${ }^{35}$}

The Supreme Court has never decided whether the rule of Johnson v. Zerbsti.e., that the sixth amendment guarantees the right to appointed counsel in felony cases-is applicable to misdemeanor cases, but language in cases subsequent to Johnson would indicate that it is..$^{36}$ If the defendant is tried in a district court,

3218 U.S.C. $\$ 1$ (1958).

3318 U.S.C. $\$ 3401$ (1958) provides in relevant part: "(a) Any United States commissioner specially designated for that purpose by the court by which he was appointed has jurisdiction to try and sentence persons committing petty offenses in any places over which the Congress has exclusive power to legislate or over which the United States has concurrent jurisdiction, and within the judicial district for which such commissioner was appointed. (b) Any person charged with a petty offense may elect, however, to be tried in the district court of the United States. The commissioner shall apprise the defendant of his right to make such election and shall not proceed to try the case unless the defendant after being so apprised, signs a written consent to be tried before the commissioner ...."

If the petty offense is committed in the District of Columbia, the defendant is tried in the muncipal court and does not have the same election, 18 U.S.C. $\$ 3401$ (e) (1958).

3* The Federal Rules of Criminal Procedure apply to commissioners and to judges of the District of Columbia municipal court only when they are acting as committing magistrates. FED. R. Cronr. P. 54(a) (2), see Notes of Advisory Committee on Rules, note to suhdivision (a) (2) of Rule 54.

35 The discussion under this beading is limited to the class of misdemeanors wbich does not include petty offenses.

36 See, e.g., Bute v. Illinois, 335 U.S. 640, 666 (1948): "The practice in the federal courts as to the right of the accused to have the assistance of counsel is derived from the Sixth Amendment which expressly requires that, in all criminal prosecutions in the courts of the United States, the accused shall have the assistance of counsel for his defense." (Emphasis added.); Foster v. Mllinois, 332 U.S. 134, 136-37 (1947): "By virtue of the [sixth amendment] . . , , counsel must be furnished to an indigent defendant prosecuted in a federal court in every case, whatever the circumstances . . . " (Emphasis added.) 
Rule 44 of the Federal Rules of Criminal Procedure would seern to guarantee this right to a person accused of a misdemeanor. ${ }^{37}$ Neither in the reports nor in the advisory committee notes is there to be found authority to the contrary.

In Evans v. Rives, ${ }^{38}$ moreover, the Court of Appeals for the District of Columbia held that the Johnson rule was applicable to a misdemeanor case. There defendant was prosecuted in the juvenile court ${ }^{39}$ and convicted of failing to provide for the support and maintenance of a minor child. ${ }^{40}$ He was not advised of his right to counsel. The court refused to accept the argument that the charge was not of such a serious nature as to brimg into operation the constitutional guarantee of a right to appointed counsel, and stated:

No such differentiation is made in the wording of the guaranty itself, and we are cited to no authority, and know of none, making this distinction. The purpose of the guaranty is to give assurance against deprivation of life or liberty except strictly according to law. The petitioner would he as effectively deprived of his liberty by a sentence to a year in jail for the crime of non-support of a minor child as by a sentence to a year in jail for any other crime, lowever serious. And so far as the right to the assistance of counsel is concerned, the Constitution draws no distinction between loss of liberty for a short period and such loss for a long one. 41

\section{Petty Offenses}

It has been held that the right to trial by jury provicled by the sixth amendinent does not extend to petty offenses, ${ }^{42}$ since the guarantee extends only to those cases in which the right had been recognized at counmon law. ${ }^{43}$ Although the right to counsel has not paralleled the right to a jury trial, it might be argued that the holding that a jury trial is not required implies that representation by appointed counsel is not a prerequisite to a fair trial in this type of case.

It must be remembered that the words of the sixth amendment do not clearly indicate that there shall be appointment of counsel in all cases and that the practice in the federal courts prior to Johnson v. Zerbst indicated that only the right to retained counsel was protected.44 Moreover, an absolute right to counsel in the trial of petty offenses could create substantial practical problems. In addition to the burden placed on members of the bar, who are not paid for their services, ${ }^{45}$ it would seem that more time would be consumed in conclucting trials, thus causing more expense for taxpayers. Additional time spent in jail by defendants awaiting trial would also increase these expenses. Also, if a significant amount of counsel's time is taken up by this type of case, the interests of those accused of more serious crimes might be adversely affected. Should the rationale underlying the

37 FEd. R. CRחM. P. 54(a) (1).

38126 F.2d 633 (D.C. Cir. 1942).

39 The juvenile court had concurrent jurisdiction with the District Court for the District of Columbia for the offense charged. D.C. CoDE tit. 6, §271 (1929).

40 D.C. CoDE tit. 6, $\$ 271$ (1929). The statute provided for a fine of not more than $\$ 500$ or for imprisodment in the workhouse of the District for not nore than twelve months, or for both fine and imprisonment.

41126 F.2d 633, 638 (1942).

42 District of Columbia v. Clawans, 300 U.S. 617 (1936); Schick v. United States, 195

U.S. 65 (1904).

43 District of Columbia v. Colts, 282 U.S. 63 (1930).

44 See note 9 supra.

45 There has been much agitation to change this. See Mars, The Problem of the Indigent Accused: Public Defenders in the Federal Courts, 45 A.B.A.J. 272 (1959). 
broad language in Evans $v$. Rives ${ }^{46}$ be accepted by the Supreme Court, however, the appointment of counsel even in these minor cases would seem to be required by the sixth amendment.

\section{B. State Courts}

\section{Protection Under the Fourteenth Amendment}

(a) Retained Counsel.-Although the Supreme Court has never decided the issue, it would be indeed surprising if the Court were to hold that a defendant in a misdemeanor case who appeared in court with counsel could be denied representation by such counsel. An application of the principles of due process would seem to preclude such a decision. Moreover, in Chandler v. Fretag, ${ }^{47}$ where the defendant was charged with a felony, the court held that the right to be heard through retained counsel is an unqualified right. ${ }^{48}$ Statements in other Supreme Court opinions $^{49}$ would seem to leave hittle doubt that this same unqualified right extends to misdemeanor cases in the state courts.

(b) Appointed Counsel.-(1) Due Process.-There have been no misdemeanor cases in which the Supreme Court has apphed the "fair-trial" rule of Betts v. Brady.50 It would appear that a very extrente case would have to be presented before the Court would overrule a state decision and hold that there had been a denial of due process because counsel was not assigned to the defendant in a misdemeanor case. Since the usual misdemeanor case does not present a difficult question of law and since the penalties are relatively hight, the other factors usually alluded to by the Court would have to combine to produce an outrageous result. The cases $^{51}$ indicate that only in serious instances, i.e., those involving heavy penalties, will the Court find that the denial of the right to counsel has resulted in a conviction that is "slocking to the universal sense of justice." sylvania, Mr. Justice Reed stated:

The philosophy behind ... these views is that the due process clause of the Fourteenth Amendment ... requires counsel for all persons eharged with serious crimes, when necessary for their adequate defense . . . .j3

40 See text accompanying note 41 supra. Should the defendant elect to be tried in the district court, Rule 44 would still not be applicable, FED. R. CRnM. P. 54(b) (4).

47348 U.S. 3 (1954).

$18 I d$. at 9.

49 See, e.g., Spano v. New York, 360 U.S. 315, 327 (1959) (concurring opinion) ("Indeed the right to assistance of counsel whom the accused has himself retained is absolute, whatever the offense for which he is on trial ...."); Anonymous v. Baker, 360 U.S. 287, 294 (1959) ("In state criminal proceedings, a defendant has an unqualified right to be represented by retained counsel ... ."); In re Groban, 352 U.S. 330, 332 (1957) ("It is clear that a defendant in a state criminal trial has an unqualified right, under the Due Process Clause, to be beard tbrough bis own counsel ...."); Powell v. Alabama, 287 U.S. 45, 68-69 (1932) ("Historically and in practice [a hearing] ... has always included the right to the aid of counsel when desired and provided by the party asserting the right .... If in any case, civil or crimmal, a state or federal court were arbitrarily to refuse to hear a party by counsel, employed by and appearing for him, it reasonably may not be doubted that such a refusal would be a denial of a hearing, and, therefore, of due process in the constitutional sense ...."). See also House v. Mayo, 324 U.S. 42, 46 (1945).

50 See text accompanying notes 19-25 supra.

51 See note 27 supra and note 53 infra.

52 Betts v. Brady, 316 U.S. 455,462 (1942).

53335 U.S. 437, 441 (1948). (Emphasis added.) Even the more liberal justices seem willing to concede that appointed counsel is not constitutionally required in the trial of a relatively 
It would also appear that the force of federalism would be too strong for the Court to enunciate a doctrine so broad that the due process clause of the fourteenth amendment would be considered to deprive the states of the power to promulgate their own procedures and policies in respect to appointment of counsel in misdemeanor cases. Since it is questionable whether the sixth amendment requires appointment of counsel to defend persons accused of petty offenses under federal law, it hardly seems probable that a right to appointed counsel in misdemeanor cases would be a requirement of due process.

(2) The Impact of Griffin v. Illinois.-The Supreme Court's decision in the leading case of Griffin v. Illinois ${ }^{54}$ has led many writers to wonder how far the equal protection clause of the fourteenth amendment will be carried in its application to state criminal proceedings. ${ }^{55}$ In that case, the equal protection and due process clauses were relied upon to prevent two indigent defendants from being denied an appeal from a conviction for armed robbery solely because they were unable to pay for a transcript of the trial. ${ }^{58}$ The Court held that although a state is not required to provide appellate review, ${ }^{57}$ if an appeal is allowed at all it must be made available equally to all persons, regardless of their financial condition.

Certainly the same approach could be used in right to counsel cases. The arguinent would be that even though a state is not required to allow defendants in misdemeanor cases to be represented by their own counsel, if it does allow it then defendants who are unable to employ their own counsel must be represented by appointed counsel. An even stronger argument would be presented if the Supreme Court were to hold that state courts must allow representation by retained counsel.

Since the right to counsel cases have always been decided on the basis of the due process clause, the Griffin case raises a substantial question as to whether this right is also governed by the equal protection clause. The case itself offers no answer. The language used seems to commingle the two clauses, and the ramifications of the equal protection clause in the area of state criminal proceedings seem

minor offense. See, e.g., Mr. Justice Douglas' dissenting opinion in Bute v. Illinois, 333 U.S. 640,682 (1948): "A man who suffers up to 20 years in prison as a penalty is undergoing one of the most serious of all punishments. It might not be nonsense to draw the Betts $v$. Brady line somewhere between that case and the case of one charged with violation of a parking ordinance, and to say the accused is entitled to counsel in the former but not in the latter."

54351 U.S. 12 (1956).

55 There has been an extensive coverage of this case in the legal periodicals. See, e.g., Schaefer, Federalism and State Criminal Procedure, to HARv. L. Rev. 1 (1956); Wilkes, Constitutional Rights of Convicted Indigents in State Criminal Proceedings Since Grifin v. Illinois, 33 TEMr. L.Q. 125 (1959); Willcox, The Grifin Case-Poverty and the Fourteenth Amendment, 43 Cornest L.Q. 1 (1957); Comment, 55 Mich. L. REv. 413 (1957); Comment, 25 U. CEI. L. REv. 161 (1957).

56 In Illinois, appeals are allowed in all criminal cases. After conviction, the defendants filed a motion in the trial court requesting that a copy of the record be furnished them without cost, since they had no funds and a transcript was required in order to prosecute an appeal. The Illinois Post-Conviction Hearing Act, Irc. REv. Stax. ch. 38, \$\$ 826-32 (1955), provided free transcripts only if constitutional errors in the trial were alleged. Suice petitioners did not contend that any constitutional errors had been made, their first motion was not made under this act. The trial court denied the first motion. Petitioners then filed a petition under the Post-Conviction Hearing Act alleging that the trial court commitled non-constitutional errors and that the trial court's refusal to provide a free transcript resulted in a denial of duc process and equal protection of the law. It was this petition which resulted in the Grifin decision.

57 McKane v. Durston, 153 U.S. 684 (1894). 
to be more speculative than certain..$^{58}$ The right to counsel cases which have reached the Court since Griffin, however, have been decided on the traditional concepts of due process which were demarked in Betts v. Brady. ${ }^{59}$ Perhaps this is explainable by interpreting Griffin to stand only for the proposition that the equal protection clause will be applicable solely to prevent denial of access to the courts because of indigence. ${ }^{60}$

(3) Practical Effect of a Supreme Court Ruling.-Many procedural barriers lie in the path of a misdemeanant who attempts to obtain a Supreme Court ruling on the right to appointment of counsel in state criminal proceedings. ${ }^{61}$ In addition to being faced with the requirements of exhausting state remedies, he would have to secure bail money in order to prevent the issue from becoming noot before a ruling could be made. ${ }^{62}$ Moreover, even if the Court reached a decision favorable to the accused, ${ }^{03}$ its decision would most likely have little practical effect. If it is assumed that such a decision would be made only in a case where an outrageous result is found, the effect would be to protect that particular defendant's rights rather than to prounulgate any doctrine of broad applicability. Such a decision would not seem to cause many states to alter their existing practices.

\section{State Law}

(a) General.-While all states except Virginia ${ }^{64}$ have provisions in their consti-

58 Further conjecture as to the importance of the Grifin case is raised by the fact that there was no opinion of the Court. Mr. Chief Justice Warren and Mr. Justices Clark and Douglas joined in the opinion of Mr. Justice Black, which gave equal weight to the due process and equal protection clauses. Justice Frankfurther concurred in a separate opinion which seemed to stress equal protection more than due process.

59 In Cash v. Culver, 358 U.S. 633, 636-37 (1959), the Court stated: "In the 17 years that bave passed since its decision in Betts $v$. Brady ... this Court, by a traditional process of inclusion and exclusion has, in a series of decisions, indicated the factors which may render state criminal proceedings without counsel so apt to result in injustice as to violate the Fourteenth Amendinent. The alleged circumstances of the present case so clearly inake it one where, under these decisions, federal organic law required the assistance of counsel that it is unnecessary here to explore the outer limits of constitutional protection in this area." See also Moore v. Michigan, 355 U.S. 155 (1957). It must be noted that in both of these cases there was found a denial of due process. Therefore it was not necessary for the Court to reach the issue of equal protection.

${ }_{80}$ Certainly a broad interpretation of Griffin would create many problems. Even if it were decided that Grifin requires appointment of counsel in felony cases only, the next logical step could well be insistence that counsel for the accused be equal in competence to the prosecuting attorney.

61 The ramifications of the doctrine of exhaustion of state remedies and.the use of habeas corpus in the rigbt to counsel cases are beyond the scope of this Comment. They are effectively treated in Fellman, The Federal Right to Counsel in State Courts, 31 NEB. L. Rev. 15, 31-48 (1952).

62 It is not unlikely that a defendant in a misdemeanor case could be indigent in respect to employment of counsel and yet have sufficient funds to post bail.

63 It is not to be lightly assumed that the Supreme Court will not be bothered by "minor" cases. See, e.g., Thompson v. City of Louisville, 362 U.S. 199 (1960) (conviction of loitering and disorderly conduct by Louisville, Kentucky pohice court, with fines totalling $\$ 20$, reversed for lack of evidence resulting in denial of due process); Tumey v. Ohio, 273 U.S. 510 (1927) (conviction of unlawfully possessing intoxicating liquor with fine of $\$ 100$ reversed on finding that judge had direct pecumary interest); Yick Wo v. Hopkins, 118 U.S. 356 (1886) (San Francisco police court judgment imposing $\$ 10$ fine, upheld by state appellate court, reversed as being in contravention of fourteenth amendment).

64 In Virginia the "law of the land clause" of the state constitution has been held to embrace the rigbt to counscl. Cottrell v. Commonwealth, 187 Va. 351,46 S.E.2d 413 (1948); Watkins v. Cominonwealth, 174 Va. 518, 6 S.E.2d 670 (1940). 
tutions respecting the right of an accused to counsel in a criminal proceeding, ${ }^{05}$ state court decisions have been based primarily on statutory provisions. Where these statutes have restricted the right to appointed counsel to capital cases, state courts have usually construed the constitutional provisions to grant the accused the right to appear with retained counsel in all cases, but not to have counsel appointed..$^{67}$ Apparently the courts of only seven states ${ }^{68}$ have given their constitutions an interpretation similar to that given the United States Constitution in Johnson v. Zerbst, i.e., that the constitutional provision includes the right to appointed counsel, as well as to retained counsel in felony cases. Only in Indiana has a constitutional right to appointed counsel been considered to extend to misdemeanor cases. ${ }^{09}$ While statutes in some states specifically extend the right to appointed counsel to misdemeanor cases, ${ }^{70}$ the majority of the states have restricted this right to prosecutions for felonies. Many state courts, moreover, act on the assumption that there is no implied duty to inform the accused of his rights. ${ }^{71}$ Failure to request appointment of counsel is considered to be a waiver of any right to counsel which might exist.

\section{(b) California.-(1) Retained Counsel.-Article I, section 13 of the California constitution provides:}

In criminal prosecutions in any court, the party accused shall have the right to appear and defend in person and with counsel.72

The constitutional requirement is supplemented by California Penal Code section 858, which provides:

When the defendant is hrought hefore the magistrate upon an arrest, either with or without a warrant, on a charge of having committed a public offense, the magistrate must immediately inform him of the charge against him, and of his right to the aid of counsel in every stage of the proceedings ....

65 For a classification of the different types of provisions see BEANEY, op. cit. supra note 2 , at 237. For an exhaustive study covering the right generally, see Fellman, The Right to Counsel Under State Law, 1955 WIs. L. Rev. 280.

66 Ata. Code tit. 15, $\$ 318$ (1940) ; Fla. Stat. §909.21 (1957); Mass. Ann. Laivis ch. 276, \$37a (1959); Miss. Code AnN. § 2505 (1942); N.C. Gen. Stat. \$15-4.1 (1951); Pa. Stat. Aws. tit. 19, § 783 (1930) ; S.C. CoDE $\$ 17-507$ (1957).

67 See, e.g., State v. Davis, 171 La. 449, 131 So. 295 (1930); Brack v. State, 187 Md. 542, 51 A.2d 171 (1947); Kissinger v. State, 147 Neh. 983, 25 N.W.2d 829 (1947), noted in 27 NEB. L. REv. 87 (1948); Milliman v. State, 156 Tex. Cr. 88, 238 S.W.2d 70 (1951).

68 California, Georgia, Indiana, Nebraska, Nevada, New Mexico, and New York. See BEANEX, op. cit. supra note 2 , at 83 .

G9 Bolkovac v. State, 229 Ind. 294, 98 N.E.2d 250 (1951).

70 Colo. Rev. Stat. Ann. \$ 39-7-29 (1953); Ky. Rev. Stat. \$ 455.010 (1956); Mich. CoMp. LAws $\$ 775.16$ (1948) (not allowed with plea of guilty); S.D. CoDE $\$ 34.1901$ (1939); Tenn. Code ANn. $\S \S 40-2002,40-2003$ (1955); W. VA. Code ANn. $\S 6190$ (1955).

While the statutory definitions of misdemeanors vary from state to state, a considerable numher of states have provisions similar to CAL. PEN. CODE $\$ 17$ ("A felony is a crime which is punishable with death or by imprisonment in the state prison. Every other crime is a misdemeanor ...."). See, e.g., Artz. Rev. Stat. Ann. § 13-103 (1956) ; Fra. Stat. § 775.08 (1957); Ga. Code Ann. \$26-101 (1953); Ky. Rev. Stat. \$431.060 (1956); Mich. Compr. Laws $\S \S 750.7-750.9$ (1948) ; UTAH. Code ANn. \$ 76-1-13 (1953); Wisc. StaT. ANn. $\$ 939.60$ (1955). Some other states have statutes which separate criminal offenses into three categories, following the federal method, see, e.g., Minn. Stat. AnN. §610.01 (1945); Nev. Rev. Stat. § 193.120 (1959).

71 Patterson v. State, 157 Fla. 304, 25 So. 2d 713 (1946); Newell v. State, 209 Miss. 653, 48 So.2d 332 (1950); Skiba v. Kaiser, 352 Mo. 424, 178 S.W.2d 373 (1944); Alexander v. O'Grady, 137 Neh. 645, 290 N.W. 718 (1940); Commonwealth ex rel. Geisel v. Ashe, $165 \mathrm{~Pa}$. Super. 41, 68 A.2d 360 (1949); James v. State, 27 Wyo. 378, 196 Pac. 1045 (1921).

72 Emphasis added. 
It seems clear from the constitutional and statutory provisions that a defendant in a misdemeanor case has the right to retained counsel. This right was recognized by the California Supreme Court in In re $M c C o y .{ }^{73}$ Petitioner was arrested on a misdemeanor charge and repeatedly requested permission to telephone a lawyer. Being denied this request, he pleaded guilty to the charge in the pohice court and was sentenced to jail. On petition for a writ of habeas corpus, the court held that the refusal to grant the defendant's request for counsel was a clear denial of his constitutional rights and remanded petitioner to the custody of the sheriff for further proceedings in conformity with his right to counsel. In the case of In re Jingles, ${ }^{74}$ petitioner sought release by habeas corpus after conviction on a misdemeanor charge. The court recognized the right to retained counsel, stating: "There can be no doubt that petitioner had the right to be represented by counsel for the constitutional guarantee extends to criminal prosecutions 'in any court whatever.' [citing the California constitution] ...."75 The court then found that petitioner had imphedly waived his right to retained counsel and discharged the writ. In In re Masching, ${ }^{78}$ the court found that the denial of a request for a continuance in order to obtain counsel, when the petitioner had not been dilatory in making his request, was a demal of his constitutional rights.77

The importance of being informed of the right to counsel was recently recognized by the court in In re Newbern. ${ }^{78}$ In this habeas corpus proceeding, petitioner sought release from custody after conviction upon a plea of guilty to being drunk in a public place, a violation of the Los Angeles Municipal Code. On the morning on which the trial court was to convene, a deputy public defender inspected the four drunk tanks adjacent to the inunicipal courtroom to ascertain whether the two hundred occupants were awake and attentive. He then spoke from a microphone in the corridor of the jail, addressing the prisoners and advising them of their rights to a speedy and public trial, to reasonable bail, and to be represented by attorneys of their own choosing. The public defender also told the prisoners that if they were unable to employ attorneys they could so inform the judge and that lie, the public defender, would represent them. The abstract of the docket of the municipal court, which was part of the record, stated: "Defendant in court duly arraigned, informed of all his legal rights." 79 The appellate court held that the defendant's conviction was in excess of the court's jurisdiction and was void because the petitioner was not advised by the court of his constitutional right to counsel..$^{80}$ The case was remanded to the municipal court with instructions

\footnotetext{
73 32 Cal. 2d 73, 194 P.2d 531 (1948).

7427 Cal. 2d 496, 165 P.2d 12 (1946).

75 Id. at 498,165 P.2d at 14 .

7841 Cal. 2d 530, 261 P.2d 251 (1953).
}

77 "Of course the defendant's right to counsel does not include the right to postpone the trial of a case indefinitely and reject the services of the public defender while defendant, at his leisure, attempts to find counsel who will serve without charge ... ." People v. Adamson, $34 \mathrm{Cal} .2 \mathrm{~d} \mathrm{320,332,} 210$ P.2d 13, 19 (1949). Nor does it include the right to be generally neglectful in securing counsel. People v. Simeone, 132 Cal. App. 2d 593, 282 P.2d 971 (1955). In this light it has been stated that in any criminal proceeding there are two types of rights involved: the right of the defendant to have adequate representation at the trial and the right of the people to place the defendant on trial on the date set. People v. Whinnery, $55 \mathrm{Cal}$. App. 2d 794, 131 P.2d 33 (1942); People v. Shaw, 46 Cal. App. 2d 768, 117 P.2d 34 (1941). See 28 So. Car. L. Rev. 183 (1955).

78168 Cal. App. 2d 472, 335 P.2d 948 (1958).

78168 Cal. App. 2d 472, 476, 335 P.2d 948, 951 (1958).

80 The trial court's ohligation to advise the defendant of his right to counsel was not fulfilled by the statement of an unseen and unknown person over a public address system who 
to permit the petitioner to withdraw his plea of guilty and appear before the court through counsel of his own choosing or through counsel appointed by the court if petitioner were financially unable to employ counsel. ${ }^{81}$ The appellate court stated that the petitioner's right to counsel of his own choosing was one granted by both the state and federal constitutions and that it was the trial court's duty to protect this right by advising the defendant of its existence. A failure to comply with this duty resulted in a deprivation of the petitioner's constitutional rights. ${ }^{82}$

\section{(2) Appointed Counsel.-California Penal Code section 987 provides:}

If the defendant appears for arraignment without counsel, he must be informed by the Court that it is his right to have counsel before being arraigned, and must be asked if he desires the aid of counsel. If he desires and is unable to employ counsel, the Court must assign counsel to defend him. 83

Although this section seems clearly to provide a statutory right to appointment of counsel even in misdemeanor cases, ${ }^{84}$ it is not certain that this right emanates directly from the California constitution. In no case has the California Supreme Court been faced squarely with the issue of the right to have counsel appointed in a misdemeanor case. The only appellate case passing on this question is People v. Agnew. ${ }^{85}$ In that case, defendant, a seventeen-year-old girl, was charged with agreeing to do a lewd act for money and with being a lewd person. Although the public defender lad represented her at the arraignment, he ceased to do so at the

was neither authorized to advise the prisoners nor to act on any request made by them. The fact that the defendant is familiar with legal procedure does not relieve the court of this duty, McCarthy v. Superior Court, 162 Cal. App. 2d 755, 328 P.2d 819 (1958), even if the defendant is a lawyer, People v. Napthaly, 105 Cal. 641, 39 Pac. 29 (1895).

81 CAL. PEN. CODE \& 1484 provides that in a habeas corpus proceeding "the court or judge must ... dispose of such party as the justice of the case may require ...." See In re McCoy, 32 Cal.2d 73, 194 P.2d 531 (1948).

82 In hight of this case it is interesting to note what the Cabifornia Supreme Court stated in In re Jingles, where the right to be represented by retained counsel was recognized but found to have been waived: "[I]t is a matter of common knowledge that it is a right which is very commonly waived in prosecutions for misdemeanors in justices' and pohice courts ...." 27 Cal. 2d 496, 498, 165 P.2d 12, 14. The facts of the Newbern case (recited in text at note 78 supra) cause one to wonder whether the waivers noted in In re Jingles had been understandingly and intelligently made. The California Supreme Court has stated that a purported waiver should be more carefully scrutinized as the offense before the court increases in gravity. In re James, 38 Cal. 2d 302, 240 P.2d 596 (1952). In Newbern, on the other hand, the court indicated that the scrutiny required is not to be reduced to a nullity, even though the case may involve the relatively minor charge of drunkenness. Of course it should be recognized that the pressures to waive the right to assistance of counsel are very strong in these minor cases since there is less delay before trial and therefore less time spent in jail. 'The efiect of a less stringent penalty as a result of a plea of guilty must also be considered.

83 Empbasis added.

84 CAI. PEN. CODE $\$ 987$ a provides: "In any case in which counsel is assigned in the superior court to defend a person who is cbarged therein with crime, or is assigned in a inumicipal or justice's court ... to represent such a person on a preliminary examination in such a court and who desires but who is unable to employ counsel, such counsel, in a county, or city and county, in which there is no public defender, or in a case in which ... the public defender has properly refused to represent the person accused, shall receive a reasonable sum for compensation and for necessary expenses, the amount of which shall be determined by the court, to be paid out of the general fund of the county ...."

There is no statutory provision for compensation of an attorney who represents a misdemeanant in a municipal or justice court. See 25 Ops. CAx. ATI'y GEN. 221 (1955). This may indicate that there was no intent that misdemeanants should bave an absolute right to counsel.

85114 Cal: App. 2d 841, 250 P.2d 369 (App. Dep't 1952). 
trial. Defendant then requested appointment of counsel but was refused, and a trial without a jury resulted in her conviction. The appellate court reversed, holding that the defendant had been unconstitutionally denied the right to counsel. It is not clear from the case upon what basis the court so held, but the defendant's low mentality seemed to be a large factor in prompting the court's conclusion. The court discussed defendant's rights under the due process clause of the fourteenth amendment ${ }^{86}$ and stated that the case was one where the need for skilled counsel was glaringly apparent, since the defendant was completely bewildered by the proceedings against her. Article I, section 13 of the California constitution was then cited and held to apply to a person brought before a police court on a misdemeanor charge, ${ }^{87}$ with no discussion of the distinction between the right to be represented by retained counsel and the right to appointed counsel. The discussion of the defendant's right under the fourteenth amendment, however, would seem to preclude an assumption that this court recognized an absolute right to appointment of counsel under the California constitution; otherwise the discussion of due process would have been superfluous.

It must also be remembered that the remanding order in $N e w b e r r^{88}$ included instructions to the trial court to appoint counsel if the petitioner were financially unable to employ counsel. It might be argued that this constitutes an implied recognition of such a right in misdemeanor cases.

In summary, it seems reasonably clear that in California failure to allow defendant to be represented by retained counsel or to advise him of this right will result in making his conviction subject to attack. The right to appointment of counsel is less clear. Although such a right seems to exist, it is uncertain whether it is an absolute right or one which accrues only in certain cases.

\section{CONCLUSION}

Perhaps the most noticeable thing about the right to counsel cases is the deep chasm between dicta as to the importance of the right and holdings as to what the right actually is.

The United States Supreme Court, when dealing with the lower federal courts, has accomplished nuch in establishing what would seem in good conscience to be the correct practice. When confronted with the issue of the right to counsel in state court proceedings, however, a majority of the Court has felt constrained to place the protection of the defendant's rights in the hands of the state courts in all but the most serious of cases. The state courts have in turn left the issue with the state legislatures, which have been slow in providing effective remedial legislation, although progress is being made.

There is no doubt that the defendant in a misdemeanor case has the right to retained counsel. This is widely recognized. ${ }^{80}$ However, a few state courts still hold that the trial court has no duty to advise the defendant of his right to retained

86 The court stated that the due process clause of the fourteenth amendment to the United States Constitution was applicable to persons charged with misdemeanors, a statement which is certainly correct. See cases cited note 63 supre. But as previously indicated, it requires a broad assumption to conclude that the defendant's right to counsel protected by the fourteenth amendment extends to appointment of counsel in misdemeanor cases. See text accoinpanying notes $50-60$ sicpra.

87 The court cited In re Jingles, 27 Cal.2d 496, 165 P.2d 12 (1946), for this proposition.

88 See text accompanying note 81 supra.

${ }^{89}$ See cases cited note 67 supra. 
counsel. ${ }^{90}$ While it may be conceded that a person should be deemed to know the substantive criminal law, it would seem unfair to require him to know all its procedural safeguards as well. One of the most important tasks of counsel is to inform the accused of his constitutional and statutory rights. If the defendant does not even know that he has a right to the aid of one who is acquainted with these rights, it would seem that these other rights are of little value.

As to the appointment of counsel for indigent defendants, it seems clear that a major factor in the failure of the courts to find such a right in misdemeanor cases is the fear that too great a burden will be placed on the effective administration of criminal proceedings. That it would be a burden is no doubt true, but in a balancing process this should not be the decisive factor. The prosecution is able to marshal all the forces of the state against the defendant. The defendant must overcome the prosecution's advantages of money, education, and experience. In such an uneven match, basic considerations of fairness would seem to require that the defendant, in at least the more serious misdemeanor cases, be aided by one who has a working knowledge of the procedures and processes involved. It is often argued, however, that the trial judge is quite capable of protecting the defendant and giving him a fair trial. This argument is convincingly rebutted by a statement of the Supreme Court in Powell v. Alabama:

But how can a judge, whose functions are purely judicial, effectively discharge the obligations of counsel for the accused? He can and should see to it that in the proceedings before the court the accused shall be dealt witb justly and fairly. He cannot investigate the facts, advise and direct the defense, or participate in those necessary conferences between counsel and accused which sometimes partake of the inviolable character of the confessional.91

There are at present three methods used to provide counsel for indigent defendants: the public defender system, the voluntary defender or legal aid bureau, and the traditional method of appointing counsel. All three have their advantages and disadvantages and a comparative analysis of the merits of each will not be attempted here.92 It is enough to say that in order to provide an adequate system of representation of indigent defendants there should be a method by which there can be regularity in appointment of counsel who are acquainted with criminal law and who can perform their duties in more than a pro forma fashion.

A basic statutory scheme should provide: (1) that the defendant be fully advised of his right to counsel; (2) that only a competent and understanding waiver be allowed; (3) that provisions for trial court recordation of the above two items be made; (4) that appointment of counsel not be within the discretion of the trial judge nor drawn arbitrarily at the misdemeanor-felony line; (5) that an effective plan be put into operation to make available counsel adequately

${ }^{80}$ See cases cited note 71 supra.

91 Powell v. Alabama, 287 U.S. 45, 61 (1932). For a startling study of what can happen when a trial judge is given almost complete discretion, see Dash, Cracks in the Foundation of Criminal Justice, 46 IrL. L. REv. 385 (1952).

92 See arguments for and against each of these methods in: BrowNELL, LEGAL Am IN THE UNITEd States (1951) ; BeANEY, op. cit. supra note 2, at 212; Dimock, The Public Defender: A Step Towards a Police State?, 42 A.B.A.J. 219 (1956); Harrington \& Getty, The Public Defender: A Progressive Step Towards Justice, 42 A.B.A.J. 1139 (1956); Holtzoff, Defects in the Administration of Criminal Justice, 9 F.R.D. 303 (1950); Pollock, The Voluntary Defender as Counsel for the Defense, 32 J. Asr. Jud. Soc'y 174 (1949); Stewart, The Public Defender System is Unsound in Principle, 32 J. Asx. Jud. Soc'y 115 (1949). California, a leader in the instigation of the public defender system, provides for county option. See CaL. Gov't CODE \$8 27700-711. 
experienced in criminal law with compensation commensurate with the position.

At the beginning of this Comment, there was quoted a statement by Mr. Justice Sutherland in Powell $v$. Alabama. It is believed that the application of that statement should not be confined to serious offenses, but that its relevance is equally pertinent to minor crimes. Until the right to counsel receives wider application, one would liesitate to say that justice and fair play are being fully accorded to the many defendants in criminal cases who face trial without the aid of counsel.

Richard H. Rahl 